\title{
AGING, HEART RATE VARIABILITY AND METABOLIC IMPACT OF OBESITY
}

\author{
Marina Rastović ${ }^{1}$, Biljana Srdić-Galić ${ }^{2}$, Otto Barak ${ }^{3}$, Edita Stokić ${ }^{4}$ and Snežana Polovina ${ }^{5,6}$
}

\begin{abstract}
${ }^{1}$ Subotica General Hospital, Department of Internal Medicine, Division of Endocrinology, Subotica, Serbia; ${ }^{2}$ University of Novi Sad, Faculty of Medicine, Department of Anatomy, Novi Sad, Serbia;

${ }^{3}$ University of Novi Sad, Faculty of Medicine, Department of Physiology, Novi Sad, Serbia; ${ }^{4}$ University of Novi Sad, Faculty of Medicine, Institute of Internal Disease, Department of Endocrinology, Diabetes and Metabolic Disorders, Novi Sad, Serbia;

${ }^{5}$ Clinical Center of Serbia, Department of Endocrinology, Diabetes and Metabolic Diseases, Belgrade, Serbia; ${ }^{6}$ University of Novi Sad, Faculty of Pharmacy, Department of Internal Medicine, Novi Sad, Serbia
\end{abstract}

SUMMARY - The relationship between aging and changes in heart rate variability (HRV) could depend on the metabolic profile of obese people, i.e. metabolically healthy obese (MHO) and metabolically unhealthy obese (MUO). We aimed to determine the age at which obesity related autonomic dysfunction becomes significant and whether it decreases differently according to metabolic profile. We analyzed HRV in 99 adults using Wildman's criteria for metabolic profile and 5-minute HRV for autonomic nervous system. In MHO, high frequency (HF) decreased in the $4^{\text {th }}$ decade of life. In MUO, standard deviation of R-R intervals (SDNN), root mean square of successive differences of all R-R intervals (RMSSD), number of adjacent intervals differing by more than $50 \mathrm{~ms}$ expressed as percentage of all intervals in the collecting period ( $\mathrm{pNN} 50$ ), HF, low frequency (LF), LF/ HF (LF divided by HF) and total power (TP) decreased in the $4^{\text {th }}$ decade of life (partial shared variance 28\%-36\%). In conclusion, an age dependent decrease of HRV occurs in MUO between the third and fifth decade of life. In MHO, HF significantly decreases around the age of 40 years. Cardiometabolic profile influences metabolic aging, altering the autonomic nervous system.

Key words: Obesity, metabolically benign; Autonomic nervous system; Parasympathetic nervous system; Sympathetic nervous system; Aging; Heart rate

\section{Introduction}

Analyzing obese people reveals that besides those with cardiometabolic risk (metabolically unhealthy obese (MUO) people) there are metabolically healthy obese (MHO), people who have a higher level of insulin sensitivity, normal values of arterial blood pressure and a desirable lipid profile ${ }^{1}$. It is not clear whether MHO people are protected from the risk of chronic diseases allied with obesity, or it is a question of delay

Correspondence to: Marina Rastovic, MD, PhD, Subotica General Hospital, Izvorska 3, 24000 Subotica, Serbia

E-mail: marinara85@gmail.com

Received March 21, 2018, accepted July 5, 2018 in the progression of complications in this subpopulation of obese people ${ }^{2}$. It is considered that the autonomic nervous system (ANS) has a role in these different outcomes ${ }^{3}$. ANS alterations can even be spotted in childhood obesity ${ }^{4}$.

Abnormal autonomic regulation, estimated through heart rate variability (HRV), is ever more cited as a link between metabolic disorders and cardiovascular events. Lower HRV is a risk factor for mortality and it precedes the appearance of many modifiable and non-modifiable risk factors for the development of cardiovascular diseases $^{5}$. The connection between obesity and low parasympathetic activity estimated through HRV is found in the early period of life ${ }^{4}$. Autonomic functions, estimated through HRV, decline with age ${ }^{6}$. 
We wanted to examine at what age in the continuum of metabolic changes in obese people, cardiac ANS activity changes. We hypothesized that, depending on the metabolic profile, there are differences in the age at which HRV decline appears. Higher HRV has been found in $\mathrm{MHO}$ compared to MUO people ${ }^{7,8}$. It would be of great interest to evaluate how the connection of cardiac-autonomic and cardio-metabolic functions interacts with the aging process in obese people.

\section{Subjects and Methods}

This cross-sectional study group included 99 obese people, 36 men and 63 women (body mass index (BMI) $\geq 30 \mathrm{~kg} / \mathrm{m}^{2}$ ), age range $19-61$ (mean age $41.28 \pm 12.15$ ) years, attending general practice in Novi Kneževac and Novi Sad during the 2013-2014 period. There were 43 premenopausal and 21 postmenopausal women. Exclusion criteria were pregnancy, smoking, alcohol consumption, use of hormone replacement therapy, use of chronotropically active medications, having an implantable pacemaker, active infection, thyroid-, adrenal- and inflammatory disease. Postmenopausal status was defined as the absence of menstrual cycle in the past one year. The study was approved by authorities in each study centre, as well as by the Ethics Committee. All subjects provided their signed voluntary informed consent. The study was conducted in accordance with the Declaration of Helsinki.

Body weight was measured using a balanced beam scale to the nearest $0.1 \mathrm{~kg}$. Body height was measured using Harpenden anthropometer (Holtain Ltd., Croswell, UK) to the nearest $0.1 \mathrm{~cm}$. BMI was calculated as a quotient of weight in kilograms and squared body height in meters. Blood pressure was measured after 5-minute rest on the left arm using Riva-Roccy sphygmomanometer. Total cholesterol and triglyceride levels were determined by the standard enzyme-based method. High-density lipoprotein (HDL)-cholesterol levels were determined by the precipitation method with sodium phospho-wolframate. Fasting glucose level was determined by the Dialab glucose GOD-PAP method. Serum insulin level was determined by ECLIA. The homeostasis model assessment of insulin resistance (HOMA-IR) was calculated as fasting glucose $(\mathrm{mmol} / \mathrm{L}) \mathrm{x}$ fasting insulin level $(\mathrm{mIU} / \mathrm{L}) / 22.5$. The high-sensitivity $\mathrm{C}$-reactive protein (hsCRP) was measured by latex enhanced nephelometry.
Metabolic profile was defined by the Wildman's criteria. Wildman's criteria for $\mathrm{MHO}$ were $\mathrm{BMI} \geq 30$ $\mathrm{kg} / \mathrm{m}^{2}$ and less than two or more of the following cardiometabolic abnormalities: blood pressure level $\geq 130 / 85 \mathrm{~mm} \mathrm{Hg}$ or antihypertensive medication usage, elevated fasting triglyceride level $(\geq 1.7 \mathrm{mmol} / \mathrm{L})$, decreased HDL-cholesterol ( $<1.3 \mathrm{mmol} / \mathrm{L}$ for women and $<1.04 \mathrm{mmol} / \mathrm{L}$ for men), elevated fasting glucose level $(\geq 5.5 \mathrm{mmol} / \mathrm{L})$ or antidiabetic medication usage, insulin resistance (HOMA-IR $>5.8,90^{\text {th }}$ percentile) and systemic inflammation $\left(\mathrm{CRP} \geq 10.28 \mathrm{mg} / \mathrm{L}, 90^{\text {th }}\right.$ percentile) $)^{9}$.

After 10 minutes of accommodation, 5-minute digital electrocardiography was recorded in sitting position (VNS-Spektr, Neurosoft, Ivanovo, Russia). A sampling rate of $1000 \mathrm{~Hz}$ was chosen and recordings were transferred to a computer. The epochs gained from the DII lead were saved in the computer for further analysis. After automated $\mathrm{R}$ wave identification, all $\mathrm{R}-\mathrm{R}$ intervals were edited by visual inspection to exclude any undesirable or ectopic beats. They were deleted with the post extra systolic beat and replaced automatically with interpolated adjacent $\mathrm{R}-\mathrm{R}$ interval values. Patients where arrhythmia was detected were excluded from the investigation. Time and frequencydomain analysis was performed. The following parameters were calculated: mean duration of all normal R-R intervals (RRNN; ms); standard deviation of R-R intervals (SDNN); root mean square of successive differences of all R-R intervals (RMSSD); and number of adjacent intervals differing by more than $50 \mathrm{~ms}$ expressed as percentage of all intervals in the collecting period (pNN50). Frequency domain measures of HRV were derived by fast Fourier transformation: low-frequency (LF; 0.04-0.15 Hz), high-frequency (HF; $0.15-0.40 \mathrm{~Hz}$ ) spectral power and total spectral power (TP; 0- $0.4 \mathrm{~Hz}$ ). LFnorm and HFnorm are normalized low and high frequencies expressed in normalized units, representing the relative values of each power component in proportion to total power minus very low frequency (VLF) component ${ }^{10}$. RRNN, SDNN and TP demonstrate overall HRV, both vagal and sympathetic influences; RMSSD, pNN50 and HF correspond to parasympathetic activity; $\mathrm{LF}$ represents sympathetic activity; and $\mathrm{LF} / \mathrm{HF}$ indicates sympathovagal balance ${ }^{10}$.

Data were analyzed using the SPSS 11.5 for Windows software. Student's t-test was used to show differ- 
Table 1. Age, cardiometabolic and cardiac-autonomic markers in MHO and MUO subjects

\begin{tabular}{|c|c|c|c|c|c|c|c|c|}
\hline & \multicolumn{2}{|c|}{ MHO men } & \multicolumn{2}{|c|}{ MHO women } & \multicolumn{2}{|c|}{ MUO men } & \multicolumn{2}{|c|}{ MUO women } \\
\hline & $\mathrm{N}=15$ & & $\mathrm{~N}=31$ & & $\mathrm{~N}=21$ & & $\mathrm{~N}=32$ & \\
\hline & $\chi$ & $\mathrm{SD}$ & $\chi$ & $\mathrm{SD}$ & $\chi$ & $\mathrm{SD}$ & $\chi$ & SD \\
\hline Age (yrs) & 38.07 & 9.38 & 38.94 & 10.92 & 41.52 & 13.35 & 44.91 & 12.51 \\
\hline Systolic BP (mm Hg) & 123 & 17.71 & 117.39 & 17.91 & 133.81 & 14.82 & 136.56 & 17.06 \\
\hline Diastolic BP (mm Hg) & 79.6 & 14.05 & 75.65 & 12.37 & 84.81 & 11.91 & 85.16 & 14.17 \\
\hline Total chol $(\mathrm{mmol} / \mathrm{L})$ & 4.77 & 1.03 & 5.4 & 1.26 & 5.28 & 1.25 & 5.52 & 1.04 \\
\hline $\mathrm{TG}(\mathrm{mmol} / \mathrm{L})$ & 1.62 & 0.77 & 1.2 & 0.45 & 2.16 & 0.98 & 2.01 & 1.05 \\
\hline HDLchol (mmol/L) & 1.2 & 0.27 & 1.59 & 0.4 & 1.12 & 0.28 & 1.39 & 0.24 \\
\hline Glycemia (mmol/L) & 5.03 & 0.46 & 5.05 & 0.53 & 6.08 & 2.05 & 5.94 & 1.32 \\
\hline Insulin (mIU/L) & 10.03 & 2.69 & 9.97 & 4.64 & 14.74 & 9.76 & 11.59 & 6.62 \\
\hline $\mathrm{CRP}(\mathrm{mg} / \mathrm{L})$ & 2.43 & 1.85 & 4.68 & 2.95 & 4.48 & 5.13 & 5.42 & 5.69 \\
\hline HOMA & 2.22 & 0.53 & 2.24 & 1.06 & 3.98 & 2.93 & 3.06 & 1.96 \\
\hline BMI $\left(\mathrm{kg} / \mathrm{m}^{2}\right)$ & 33.12 & 2.41 & 33.95 & 3.69 & 35.91 & 4.22 & 37.02 & 4.07 \\
\hline RRNN (ms) & 867.93 & 151.925 & 851.97 & 94.261 & 827 & 148.144 & 807.91 & 97.638 \\
\hline SDNN (ms) & 41.67 & 15.065 & 48.58 & 18.523 & 39.33 & 17.693 & 36.69 & 15.831 \\
\hline RMSSD (ms) & 31.6 & 18.438 & 40.77 & 21.261 & 27.76 & 17.972 & 27.09 & 16.288 \\
\hline pNN50 (\%) & 13.39 & 16.651 & 18.74 & 17.149 & 9.21 & 12.9 & 7.39 & 11.36 \\
\hline $\mathrm{LF}\left(\mathrm{ms}^{2}\right)$ & 779.87 & 805.405 & 814.19 & 664.237 & 731.21 & 767.456 & 495.29 & 475.462 \\
\hline $\mathrm{HF}\left(\mathrm{ms}^{2}\right)$ & 432.77 & 335.96 & 793 & 699.116 & 530.51 & 657.175 & 375.56 & 482.967 \\
\hline $\mathrm{LF} / \mathrm{HF}$ & 2.34 & 1.438 & 1.41 & 0.939 & 2.21 & 1.684 & 1.48 & 0.997 \\
\hline $\mathrm{TP}\left(\mathrm{ms}^{2}\right)$ & 2912.67 & 2179.939 & 2854.06 & 2051.474 & 2157.71 & 1932.227 & 1739.5 & 1291.665 \\
\hline LFnorm (nu) & 64.02 & 16.511 & 53.43 & 14.337 & 62.73 & 13.968 & 56.7 & 13.226 \\
\hline HFnorm (nu) & 35.98 & 16.511 & 46.57 & 14.337 & 37.27 & 13.968 & 43.3 & 13.226 \\
\hline
\end{tabular}

$\mathrm{MHO}=$ metabolically healthy obese; $\mathrm{MUO}=$ metabolically unhealthy obese; $\mathrm{BP}=$ blood pressure; Total chol = total cholesterol; $\mathrm{TG}=$ triglycerides; HDLchol = high-density lipoprotein cholesterol; $\mathrm{CRP}=\mathrm{C}$-reactive protein; HOMA = index of insulin resistance; $\mathrm{BMI}=$ body mass index; HRV = heart rate variability; $\mathrm{HF}$ = high frequencies; $\mathrm{LF}=$ low frequencies; LFnorm = normalized low frequencies; $\mathrm{HF}$ norm $=$ normalized high frequencies; $\mathrm{LF} / \mathrm{HF}=$ ratio of low to high frequencies; $\mathrm{pNN} 50=$ proportion of interval differences of successive normal-to-normal intervals greater than $50 \mathrm{~ms}$; TP = total power; RMSSD = square root of the mean of the sum of the squares of differences between adjacent normal-to-normal intervals; RRNN = mean duration of all normal R-R intervals; $\mathrm{SDNN}=$ standard deviation of normal-to-normal intervals; $\chi=$ mean; $\mathrm{SD}=$ standard deviation

ences in age and HRV variables between $\mathrm{MHO}$ and MUO. Data that did not have normal distribution were logarithmically transformed (ln). These were pNN50 and $\mathrm{TP}$ in $\mathrm{MHO}$, and $\mathrm{pNN} 50$ and $\mathrm{LF} / \mathrm{HF}$ in MUO. One-factor analysis of variance was used to examine whether there were statistically significant differences in HRV markers among different age categories in both $\mathrm{MHO}$ and MUO subjects. In cases where variables were not homogeneous, the Welch statistics was used.

\section{Results}

Table 1 shows the mean values and standard deviation of cardiometabolic factors and HRV markers in
MHO and MUO men and women included in the study. Table 2 presents HRV marker differences in age subgroups of $\mathrm{MHO}$ subjects.

In the MHO subgroup, none of the subjects was in the 60-64 age group, so this category was excluded from analysis. In the $\mathrm{MHO}$ age groups, a statistically significant difference was only recorded for HF; the youngest group had the highest HF marker, while the oldest group had the lowest HF. The most significant decrease in HF was found between 19-29 and 30-39 years of age (right after the period of 19-29 years of age).

In the MUO subgroup, HRV-age subgroup differences were found in SDNN, RMSSD, InpNN50, $\operatorname{lnLF}, \operatorname{lnHF}$ and TP (Table 3). The size of the effects 
Table 2. HRV markers in age categories of MHO subjects

\begin{tabular}{|c|c|c|c|c|c|c|c|c|}
\hline \multirow{2}{*}{ Dependent variable } & \multirow{2}{*}{$\mathrm{F}$} & \multirow{2}{*}{ df1 } & \multirow{2}{*}{ df2 } & \multirow{2}{*}{$\mathrm{p}$} & \multirow{2}{*}{ Part $\eta^{2}$} & \multicolumn{3}{|c|}{ Difference between groups ${ }^{\mathrm{b}}$} \\
\hline & & & & & & Age (years) & $\mathrm{M}$ & Diff. $^{\circ}$ \\
\hline \multirow{4}{*}{ RRNN } & 1.394 & 3 & & 0.258 & 0.091 & $19-29$ & 804.30 & A \\
\hline & & & & & & $30-39$ & 851.81 & A \\
\hline & & & & & & $40-49$ & 870.10 & A \\
\hline & & & & & & $50-59$ & 905.70 & A \\
\hline \multirow[t]{4}{*}{ SDNN } & 2.009 & 3 & & 0.127 & 0.126 & $19-29$ & 55.60 & A \\
\hline & & & & & & $30-39$ & 48.13 & A \\
\hline & & & & & & $40-49$ & 42.50 & A \\
\hline & & & & & & $50-59$ & 38.00 & A \\
\hline \multirow[t]{4}{*}{ RMSSD } & 1.892 & 3 & & 0.146 & 0.119 & $19-29$ & 48.40 & A \\
\hline & & & & & & $30-39$ & 40.06 & A \\
\hline & & & & & & $40-49$ & 32.30 & A \\
\hline & & & & & & $50-59$ & 29.00 & A \\
\hline \multirow[t]{4}{*}{$\operatorname{lnpNN50}$} & 1.816 & 3 & 42 & 0.159 & 0.115 & $19-29$ & 2.75 & A \\
\hline & & & & & & $30-39$ & 2.56 & A \\
\hline & & & & & & $40-49$ & 1.90 & A \\
\hline & & & & & & $50-59$ & 1.68 & A \\
\hline \multirow[t]{4}{*}{$\mathrm{LF}$} & 2.361 & 3 & & 0.085 & 0.144 & $19-29$ & 1138.20 & A \\
\hline & & & & & & $30-39$ & 905.81 & A \\
\hline & & & & & & $40-49$ & 737.70 & A \\
\hline & & & & & & $50-59$ & 368.60 & A \\
\hline \multirow[t]{4}{*}{$\mathrm{HF}$} & $3.270^{\mathrm{a}}$ & 3 & 20.217 & 0.005 & 0.197 & $19-29$ & 1115.10 & A \\
\hline & & & & & & $30-39$ & 731.88 & A. B \\
\hline & & & & & & $40-49$ & 471.28 & B \\
\hline & & & & & & $50-59$ & 350.08 & $\mathrm{~B}$ \\
\hline \multirow[t]{4}{*}{$\mathrm{LF} / \mathrm{HF}$} & 0.615 & 3 & & 0.587 & 0.044 & $19-29$ & 1.57 & A \\
\hline & & & & & & $30-39$ & 1.49 & A \\
\hline & & & & & & $40-49$ & 2.14 & A \\
\hline & & & & & & $50-59$ & 1.78 & A \\
\hline \multirow[t]{4}{*}{$\operatorname{lnTP}$} & 1.241 & 3 & & 0.307 & 0.081 & $19-29$ & 8.05 & A \\
\hline & & & & & & $30-39$ & 7.75 & A \\
\hline & & & & & & $40-49$ & 7.64 & A \\
\hline & & & & & & $50-59$ & 7.47 & A \\
\hline \multirow[t]{4}{*}{ LFnorm } & $0.158^{\mathrm{a}}$ & 3 & 19.159 & 0.924 & 0.015 & $19-29$ & 55.17 & A \\
\hline & & & & & & $30-39$ & 55.96 & A \\
\hline & & & & & & $40-49$ & 60.44 & A \\
\hline & & & & & & $50-59$ & 56.51 & A \\
\hline \multirow[t]{4}{*}{ HFnorm } & $0.158^{\mathrm{a}}$ & 3 & 19.159 & 0.924 & 0.015 & $19-29$ & 44.83 & A \\
\hline & & & & & & $30-39$ & 44.04 & A \\
\hline & & & & & & 40-49 & 39.56 & A \\
\hline & & & & & & $50-59$ & 43.49 & A \\
\hline
\end{tabular}

${ }^{a}$ Welch test; ${ }^{b}$ LSD test; ' groups that do not share the same letter differ (diff.- difference)

$\mathrm{F}=$ ANOVA test; $\mathrm{p}=$ level of statistical significance; $\mathrm{Part} \eta^{2}=$ partial shared variance; $\mathrm{HRV}=$ heart rate variability; $\mathrm{MHO}=$ metabolically healthy obese; $\mathrm{HF}=$ high frequencies; $\mathrm{LF}=$ low frequencies; LFnorm = normalized low frequencies; HFnorm = normalized high frequencies; $\mathrm{LF} / \mathrm{HF}=$ ratio of low to high frequencies; $\ln$ NN50 = logarithmically transformed proportion of interval differences of successive normal-to-normal intervals greater than $50 \mathrm{~ms} ; \operatorname{lnTP}=$ logarithmically transformed total power; RMSSD = square root of the mean of the sum of the squares of differences between adjacent normal-to-normal intervals; RRNN = mean duration of all normal R-R intervals; SDNN = standard deviation of normal-to-normal intervals 
Table 3. HRV in age categories of MUO subjects

\begin{tabular}{|c|c|c|c|c|c|c|c|c|}
\hline & & & & & & Group dif & & \\
\hline Dependent variable & $\mathrm{F}$ & df1 & $\mathrm{d}+2$ & $\mathrm{p}$ & Part $\eta^{2}$ & Age (yrs) & M & Diff. \\
\hline RRNN & 1.794 & 4 & & 0.145 & 0.130 & $\begin{array}{l}19-29 \\
30-39 \\
40-49 \\
50-59 \\
60-64\end{array}$ & $\begin{array}{l}771.75 \\
855.88 \\
768.11 \\
784.82 \\
867.33\end{array}$ & $\begin{array}{l}\mathrm{A} \\
\mathrm{A} \\
\mathrm{A} \\
\mathrm{A} \\
\mathrm{A}\end{array}$ \\
\hline SDNN & 4.765 & 4 & & 0.003 & 0.284 & $\begin{array}{l}19-29 \\
30-39 \\
40-49 \\
50-59 \\
60-64\end{array}$ & $\begin{array}{l}52.75 \\
43.75 \\
29.44 \\
30.09 \\
31.33\end{array}$ & $\begin{array}{l}\mathrm{A} \\
\mathrm{A} \\
\mathrm{B} \\
\mathrm{B} \\
\mathrm{B}\end{array}$ \\
\hline RMSSD & 4.912 & 4 & & 0.002 & 0.290 & $\begin{array}{l}19-29 \\
30-39 \\
40-49 \\
50-59 \\
60-64\end{array}$ & $\begin{array}{l}44.13 \\
32.38 \\
18.56 \\
20.18 \\
21.11\end{array}$ & $\begin{array}{l}\text { A } \\
\text { A. C } \\
\text { B } \\
\text { B } \\
\text { B. C }\end{array}$ \\
\hline $\operatorname{lnpNN50}$ & 6.841 & 4 & & 0.000 & 0.363 & $\begin{array}{l}19-29 \\
30-39 \\
40-49 \\
50-59 \\
60-64\end{array}$ & $\begin{array}{l}2.61 \\
2.03 \\
0.77 \\
0.61 \\
0.91\end{array}$ & $\begin{array}{l}\text { A } \\
\text { A } \\
\text { B } \\
\text { B } \\
\text { B }\end{array}$ \\
\hline $\operatorname{lnLF}$ & 6.482 & 4 & & 0.000 & 0.351 & $\begin{array}{l}19-29 \\
30-39 \\
40-49 \\
50-59 \\
60-64\end{array}$ & $\begin{array}{l}6.94 \\
6.31 \\
5.48 \\
5.23 \\
5.16\end{array}$ & $\begin{array}{l}\text { A } \\
\text { A } \\
\text { B } \\
\text { B } \\
\text { B }\end{array}$ \\
\hline $\operatorname{lnHF}$ & 5.926 & 4 & & 0.001 & 0.331 & $\begin{array}{l}19-29 \\
30-39 \\
40-49 \\
50-59 \\
60-64\end{array}$ & $\begin{array}{l}6.41 \\
5.97 \\
5.10 \\
4.74 \\
4.63\end{array}$ & $\begin{array}{l}\mathrm{A} \\
\mathrm{A} \\
\mathrm{B} \\
\mathrm{B} \\
\mathrm{B}\end{array}$ \\
\hline $\operatorname{lnLF} / \mathrm{HF}$ & 0.972 & 4 & & 0.432 & 0.075 & $\begin{array}{l}19-29 \\
30-39 \\
40-49 \\
50-59 \\
60-64\end{array}$ & $\begin{array}{l}0.19 \\
0.19 \\
0.37 \\
0.49 \\
0.64\end{array}$ & $\begin{array}{l}\mathrm{A} \\
\mathrm{A} \\
\mathrm{A} \\
\mathrm{A} \\
\mathrm{A}\end{array}$ \\
\hline TP & 5.133 & 4 & & 0.002 & 0.300 & $\begin{array}{l}19-29 \\
30-39 \\
40-49 \\
50-59 \\
60-64\end{array}$ & $\begin{array}{l}3438.88 \\
2444.38 \\
1166.44 \\
1185.27 \\
1202.11\end{array}$ & $\begin{array}{l}\mathrm{A} \\
\mathrm{A} \\
\mathrm{B} \\
\mathrm{B} \\
\mathrm{B}\end{array}$ \\
\hline LFnorm & 0.656 & 4 & & 0.626 & 0.052 & $\begin{array}{l}19-29 \\
30-39 \\
40-49 \\
50-59 \\
60-64 \\
\end{array}$ & $\begin{array}{l}54.18 \\
57.76 \\
58.38 \\
60.94 \\
64.29\end{array}$ & $\begin{array}{l}\mathrm{A} \\
\mathrm{A} \\
\mathrm{A} \\
\mathrm{A} \\
\mathrm{A}\end{array}$ \\
\hline HFnorm & 0.656 & 4 & & 0.626 & 0.052 & $\begin{array}{l}19-29 \\
30-39 \\
40-49 \\
50-59 \\
60-64 \\
\end{array}$ & $\begin{array}{l}45.83 \\
42.24 \\
41.62 \\
39.06 \\
35.71 \\
\end{array}$ & $\begin{array}{l}\mathrm{A} \\
\mathrm{A} \\
\mathrm{A} \\
\mathrm{A} \\
\mathrm{A}\end{array}$ \\
\hline
\end{tabular}

aLSD test; 'broups that do not share the same letter differ (diff.-difference); F-ANOVA test $\mathrm{p}=$ level of statistical significance; Part $\eta^{2}=$ partial shared variance; $\mathrm{HRV}=$ heart rate variability; $\mathrm{MUO}=$ metabolically unhealthy obese people; $\operatorname{lnHF}=$ logarithmically transformed high frequencies; $\operatorname{lnLF}=$ logarithmically transformed low frequencies; LFnorm = normalized low frequencies; HFnorm = normalized high frequencies; $\operatorname{lnLF} / \mathrm{HF}=\operatorname{logarithmically~transformed~ratio~of~low~to~high~frequencies;~}$ $\operatorname{lnpNN50}=$ logarithmically transformed proportion of interval differences of successive normal-to-normal intervals greater than $50 \mathrm{~ms}$; TP = total power; RMSSD = square root of the mean of the sum of the squares of differences between adjacent normal-to-normal intervals; $\mathrm{RRNN}$ = mean duration of all normal R-R intervals; SDNN = standard deviation of normal-to-normal intervals 
ranged from $28 \%$ to $36 \%$ (around 30\% of variance of difference in HRV marker could be attributed to age difference). Practically in each case, the youngest category had the highest scores, which decreased with increasing age, up to the age category of 40-49 years. After this category, the results were in stagnation. The most significant decrease in HRV markers occurred between 19-29 and 40-49 years of age. Only in case of variable RMSSD, the age category of 30-39 years did not differ from the age category of $60-64$ years. It is interesting that in MUO, HRV differences between age categories had relatively large effects. In each case, except for $\operatorname{lnLF} / \mathrm{HF}$, LFnorm and HFnorm, the size of the effect was around $30 \%$. The results indicated that differences in age categories of HRV were more prominent and significant in $\mathrm{MUO}$ as compared to $\mathrm{MHO}$ subjects.

\section{Discussion}

Lower HRV is independently associated with lipid metabolism derangement, poor glycemic uptake, coronary heart disease, myocardial infarction, and above all, mortality ${ }^{11}$. It is surely possible that ANS is included in the cascade of dysmetabolic events which allies central obesity with insulin resistance ${ }^{12}$. Central place in cardiac autonomic neuropathy belongs to the impaired glycemic control ${ }^{11}$. Other contributing factors are age, obesity, nephropathy, peripheral neuropathy, retinopathy, hypertension and smoking ${ }^{11}$. We found HRV to decrease with age, precisely in the fourth decade of life in MUO subjects. In MHO subjects, the decade of life-related decrease in HRV measures was not statistically significant, except for significant differences in HF marker. In our study, age correlated significantly negatively with RMSSD, LF and TP in men and with all HRV measures in women (not shown in tables), supporting previous reports on HRV decline with age $^{6}$. HRV differences between MHO and MUO subjects are statistically significantly influenced by age ${ }^{8}$. Lower HRV is more closely connected to the metabolic risk in obese individuals with increasing age ${ }^{8}$. It has been shown that HRV is reduced in women compared to men with the same nutritional level ${ }^{6,13}$. In contrast to this, in our investigation $\mathrm{MHO}$ women had higher HFnorm and lower LF/HF and LFnorm compared to MHO men, while in MUO subjects there were no sex differences in HRV markers (not shown in tables). Tendency of HRV decrease in female is connected to lowering of the estrogen level in menopause $^{14}$. Unlike women, men do not experience sudden decline in sex hormones during aging ${ }^{15}$.

Reduced HRV is connected to the higher level of obesity $^{16}$, hypertension, coronary heart disease, diabetes, hyperlipidemia, and other components of metabolic syndrome ${ }^{17}$. There were no differences in nutritional level and age between men and women (not shown in tables).

Lower HRV has been established as an independent predictor of elderly people mortality ${ }^{18,19}$. Central obesity in adolescents correlates with change in cardiac autonomic control, suggesting that impairment in cardiovascular system begins in childhood ${ }^{20}$. Gutin et al. suggest that, concerning the fact that HRV decreases from $10^{\text {th }}$ to $99^{\text {th }}$ year of life, life habits that can help the child develop higher levels of HRV at an early age could preserve higher HRV at an older age and slow down some aspects of the aging process ${ }^{19}$. Our results are in line with this, supporting the necessity of preserving appropriate metabolic profile in order to slow down the autonomic aspect of aging. Also, we highlight the age period when this ANS deprivation could start. It is hard to preserve increment of HRV, but decrement could be prevented with healthy lifestyle. Based on their results, Uusitalo et al. concluded that in the disease group, modifiable and lifestyle factors influenced autonomic balance more than genetic factors and that changeable factors, including anthropometric factors, could be the main factors in $\mathrm{LF} / \mathrm{HF}$ change in diseased twins ${ }^{18}$.

Association of fat mass distribution to cardiac autonomic nervous activity is not independent and could be attributed to the aging process $^{8}$. Lower sympathetic activity in central fat mass ${ }^{21}$ allied with tendency of visceral fat mass towards insulin resistance, with aging allows further fat mass expansion in the central region $^{22}$. This, in turn, leads to the age dependent decline in autonomic activities ${ }^{22}$.

Aging process is characterized by progressive deprivation in physiological functions, leading to a higher risk of diseases, especially cardiovascular. There is a global tendency of human aging. Age is one of the most important correlates with autonomic nervous functions, as also confirmed in this study. HF decreases with age, independently of $\operatorname{sex}^{23}$. In our study, HF was the only marker that differed between age groups 
in MHO. Decreasing trend of HF was significant in the period between third and fifth decade of life. In MUO, most of HRV measures showed a statistically significant decline between third and fifth decade of life.

Uusitalo et al. report that age has significant effects on HRV, except for $\mathrm{LF} / \mathrm{HF}^{18}$. Since in our study, $\mathrm{MHO}$ women differed from men in LF/HF (not shown in tables), we did not interpret this marker in the analysis of HRV differences among age subgroups Still, MUO age groups did not differ in LF/HF.

Some researchers used 24-hour HRV, others used 5-minute HRV. In both cases, results are the same concerning age, demonstrating age to have direct negative effect on $\mathrm{HRV}^{17}$. Based on our results, this impact of age appeared to be more pronounced in MUO subjects, leading to a more prominent HRV deprivation. Parasympathetic modulation in $\mathrm{MHO}$ changed and decreased during fourth decade of life. In MUO, both sympathetic and parasympathetic heart modulations decreased during fourth decade of life. In older age, there was stagnation of HRV levels in MUO (starting from 40-49 years of life), pointing to the essential need for earlier prevention of HRV derangement. The most dramatic fall in HRV could be seen between age 19-29 and 40-49.

In mice, the increasing number of neuron-specific substrates for insulin receptors leads to lowering of the locomotive activity, enlargement of fat mass, insulin resistance and glucose intolerance allied with age ${ }^{24}$. Obesity and its complications such as insulin resistance provoke autoimmune reactions, leading to earlier presentation of diabetes ${ }^{25}$. It is possible there is a specific trigger that in MUO provokes faster aging. In line with our finding that the most significant decrease in HRV occurs during fourth decade of life, sarcopenia also begins in fourth decade, leading to metabolic stress and metabolic disorders ${ }^{26}$. It is possible that enlargement of fat mass together with loss of muscle mass, which takes place from fourth decade of life (when autonomic decrease is notable), presents together with autonomic impairment associated with the aging process. Aging process is connected to metabolic and fat mass distribution changes and insulin resistance. Based on these results, faster aging is connected with autonomic decrease as well.

The exact mechanism how fat mass influences autonomic functions is still not clear, but it is known that adipose cells are responsible for the secretion of adipokines, e.g., leptin and adiponectin. Leptin is responsible for activation of neural signaling ways, which leads to sympathetic activity ${ }^{20}$. In old rats that were converted to metabolically 'young' profile using restrictive diet, leptin resistance could not be corrected. There is an age-dependent reinforcement of the blood-brain barrier for leptin transmission. Age-dependent weakening of leptin transmission could be connected to lipotoxic and metabolic effects of age ${ }^{27}$. Leptin resistance could be connected with metabolic aging ${ }^{27}$. In the same way, increased cardiometabolic risk, insulin resistance allied with autonomic neuropathy and ANS resistance of MUO people could be connected with earlier metabolic aging of the body.

For now, fourth decade of life appears to be the period of time when the autonomic-metabolic aging process starts manifesting its cardiac autonomic dysregulation in obese people. These circumstances present themselves more prominently in MUO profiles. The results of this study point to the necessity of preventing autonomic imbalance underlying obesity, early medication for metabolic changes and detection of invisible complications in obesity, all in order to avoid premature aging.

\section{Acknowledgment}

We acknowledge the contribution offered by the staff of Novi Kneževac Health Centre and GP Medical from Novi Sad, Serbia.

\section{References}

1. Karelis AD, Faraj M, Bastard JP, St-Pierre DH, Brochu M, Prud'homme D, et al. The metabolically healthy but obese individual presents a favorable inflammation profile. J Clin Endocrinol Metab. 2005;90:4145-50. doi: 10.1210/jc.2005-0482

2. Hinnouho GM, Czernichow S, Dugravot A, Nabi H, Brunner EJ, Kivimaki M, et al. Metabolically healthy obesity and the risk of cardiovascular disease and type 2 diabetes: the Whitehall II cohort study. Eur Hearth J. 2015;36:551-9. doi:101093/ eurheartj/ehu123

3. Kreier F, Fliers E, Voshol PJ, Van Eden CG, Havekes LM, Kalsbeek A, et al. Selective parasympathetic innervation of subcutaneous and intra-abdominal fat - functional implications. J Clin Invest. 2002;110:1243-50. doi: 10.1172/JCI15736

4. Baum P, Petroff D, Classen J, Kiess W, Blüher S. Dysfunction of autonomic nervous system in childhood obesity: a crosssectional study. PLoS ONE. 2013;8:e54546. doi: 101371/journalpone 0054546 
5. Hu DD. Ethnic, Sex, Age, and Socioeconomic Differences in Heart Rate Complexity and Variability: The Healthy Aging in Neighborhoods of Diversity across the Life Span [HANDLS] Study [dissertation]. The Ohio State University; 2011.

6. Stein PK, Barzilay JI, Chaves PH, Traber J, Domitrovich PP, Heckbert SR, et al. Higher levels of inflammation factors and greater insulin resistance are independently associated with higher heart rate and lower heart rate variability in normoglycaemic older individuals: the Cardiovascular Health Study. J Am Geriatr Soc. 2008;56:315-21. doi: 10.1111/j.1532-5415 .2007.01564.x

7. Robbillard ME, Bellefeuille P, Comtois AS, Aubertrin-Leheudre M, Karelis AD. The metabolically healthy but obese postmenopausal women present a favorable heart rate variability profile. Scand Cardiovasc J. 2011;45:316-20. doi: 10.3109/14 017431.2011.591818

8. Rastovic M, Srdic-Galic B, Barak OF, Stokic EJ, Vasiljev R. Heart rate variability in metabolically healthy and metabolically unhealthy obese premenopausal women. Acta Endocrinol (Buchar). 2016;12:35-42. doi: 10.4183/aeb.2016.35

9. Wildman RP, Muntner P, Reynolds K, McGinn AP, Rajpathak $\mathrm{S}, \mathrm{Wylie}$-Rosett J, et al. The obese without cardiometabolic risk factor clustering and the normal weight with cardiometabolic risk factor clustering. Arch Intern Med. 2008;168:1617-24. doi: 10.1001/archinte.168.15.1617

10. Task Force of the European Society of Cardiology and the North American Society of Pacing and Electrophysiology. Heart rate variability: standards of measurement, physiological interpretation and clinical use. Circulation. 1996;93:1043-65.

11. Nolan RP, Barry-Bianchi SM, Mechetiuc AE, Chen MH. Sexbased differences in the association between duration of type 2 diabetes and heart rate variability. Diab Vasc Dis Res. 2009; 6:276-82. doi:10.1177/1479164109339965

12. Lindmark S, Lönn L, Wiklund U, Tufvesson M,Olsson T, Eriksson JW. Dysregulation of the autonomic nervous system can be a link between visceral adiposity and insulin resistance. Obes Res. 2005;13:717-28. doi:10.1038/oby.2005.81

13. Pavithran P, Madanmohan T, Nandeesha H. Sex differences in short-term heart rate variability in patients with newly diagnosed essential hypertension. J Clin Hypertens (Greenwich). 2008;10:904-10. doi: 10.1111/j.1751-7176.2008.00052

14. Neves VF, Silva de Sá MF, Gallo L Jr, Catai AM, Martins LE, Crescêncio JC, et al. Autonomic modulation of heart rate of young and postmenopausal women undergoing estrogen therapy. Braz J Med Biol Res. 2007;40:491-9. doi: 10.1590/S0100879X2006005000080

15. Muller M, den Tonkelaar I, Thijssen JHH, Grobbee DE, van der Schouw YT. Endogenous sex hormones in men aged 40-80 years. Eur J Endocrinol. 2003;149:583-9. doi: 10.1530/ eje. 0.1490583

16. Laederach-Hofman K, Mussgay L, Ruddel H. Autonomic cardiovascular regulation in obesity. J Endocrinol. 2000;164: 59-66. doi: 10.1677 /joe.0.1640059

17. Chen GY, Hsiao TJ, Lo HM, Kuo CD. Abdominal obesity is associated with autonomic nervous derangement in healthy Asian obese subjects. Clin Nutr. 2008;27:212-27. doi: 10.1016 /j.clnu.2007.11.004

18. Uusitalo ALT, Vanninen E, Levälahti E, Battie MC,Videman $\mathrm{T}$, Kaprio J. Role of genetic and environmental influences on heart rate variability in middle-aged men. Am J Physiol Heart Circ Physiol. 2007;293:H1013-22. doi: 10.1152/ajpheart.00 475.2006

19. Gutin B, Barbeau P, Litaker MS, Ferguson M, Owens S. Heart rate variability in obese children: relations to total body and visceral adiposity, and changes with physical training and detraining. Obes Res. 2000;8:12-9. doi: 10.1038/oby.2000.3

20. Farah BQ, Prado WL, Tenorio TR, Ritti-Dias RM. Heart rate variability and its relationship with central and general obesity in obese normotensive adolescents. Einstein (Sao Paulo). 2013 JulSep;11(3):285-90. doi: 10.1590/S1679-45082013000300005

21. Coppack SW. Adipose tissue changes in obesity. Biochem Soc Trans. 2005;33:1049-52. doi: 10.1042/BST20051049

22. Christou DD, Parker Jones P, Pimentel AE, Seals DR. Increased abdominal-to-peripheral fat distribution contributes to altered autonomic-circulatory control with human aging. Am J Physiol Heart Circ Physiol. 2004;287:H1530-7. doi: 10.1152/ ajpheart.00322.2004

23. Esco MR, Williford HN. Relationship between post-exercise heart rate variability and skinfold thickness. SpringerPlus. 2013;2:389. doi: 10.1186/2193-1801-2-389

24. Zemva J, Udelhoven M, Moll L, Freude S, Stöhr O, Brönneke HS, et al. Neuronal overexpression of insulin receptor substrate 2 leads to increased fat mass, insulin resistance, and glucose intolerance during aging. Age. 2013;35:1881-97. doi: 10.1007/ s11357-012-9491-x

25. Samardžić M, Martinović M, Nedović-Vuković M, PopovićSamardžić M. Recent incidence of type 1 diabetes mellitus in Montenegro: a shift toward younger age at disease onset. Acta Clin Croat. 2016;55:63-8. doi: 10.20471/acc.2016.55.01.10

26. Karakelides H, Nair KS. Sarcopenia of aging and its metabolic impact. Curr Top Dev Biol. 2005;68:123-48. doi: 10.1016/ S0070-2153(05)68005-2

27. Gabriely I, Ma XH, Yang XM, Rossetti L, Barzilai N. Leptin resistance during aging is independent of fat mass. Diabetes. 2002;51:1016-21. doi: 10.2337/diabetes.51.4.1016 
Sažetak

\title{
STARENJE, VARIJABILNOST SRČANE FREKVENCIJE I METABOLIČKI UTJECAJ PRETILOSTI
}

\author{
M. Rastović, B. Srdić-Galić, O. Barak, E. Stokić i S. Polovina
}

Dobne promjene u varijabilnosti srčane frekvencije (HRV) mogu zavisiti o metaboličkom profilu pretilih osoba, tj. metabolički zdrave (MHO) i metabolički rizične pretile osobe (MUO). Željeli smo utvrditi dob u kojoj nastupa autonomna disfunkcija povezana s pretilošću te opada li HRV različito kod osoba različitog metaboličkog profila. Analizirali smo HRV kod 99 odraslih osoba uz primjenu Wildmanovih kriterija metaboličkog profila i HRV kao aktivnosti autonomnog živčanog sustava. Kod MHO, visoka frekvencija (HF) opadala je u 4. desetljeću života. Kod MUO su standardna devijacija svih R-R intervala (SDNN), kvadratni korijen srednje razlike između sukcesivnih normalnih R-R intevala (RMSSD), postotak sukcesivnih R-R intervala vrijednost kojih prelazi $50 \mathrm{~ms}$ (pNN50), HF, niska frekvencija (LF), omjer LF i HF (LF/HF) i ukupna spektralna snaga (TP) opadali u 4. desetljeću života (parcijalna podijeljena varijanca 28\%-36\%). U zaključku, utvrđen je od dobi zavisan pad HRV kod MUO između trećeg i petog desetljeća života. Kod MHO osoba HF je značajno opala oko 40. godine života. Kardiometabolički profil utječe na starenje remeteći funkcije autonomnog živčanog sustava.

Ključne riječi: Pretilost, metabolički benigna; Autonomni živčani sustav; Parasimpatički živčani sustav; Simpatički živčani sustav; Starenje; Srčana frekvencija 